\title{
Italian Greyhound
}

National Cancer Institute

\section{Source}

National Cancer Institute. Italian Greyhound. NCI Thesaurus. Code C53935.

The Italian Greyhound is a miniature Greyhound with a long head thinning gradually to a pointed muzzle. It has a high-stepping gait. The narrow ears fold back along the head, but rise perpendicular to the head when the dog is alert. It has a short, sleek coat in solid gray, slate gray, cream, red, fawn, black, or blue - often broken up with white markings on the chest and feet, or white with color markings. Height: 12-15 inches $(30-38 \mathrm{~cm}$.)

Weight: 6-10 pounds (3-5 kg.) There are two weight varieties: 8 pounds (4 kg.) maximum, and over 8 pounds (4 kg.) 